\title{
$\bullet$ \\ IJCRR \\ The Myelogram: Its Contribution to the Diagnosis of Hemopathies
}

Section: Healthcare

Sci. Journal Impact

Factor: 5.385 (2017)

ICV: $71.54(2015)$

\section{Boufrioua El Ghali ${ }^{1}$, Belkhair jihane ${ }^{1}$, Allali Asma ${ }^{1}$, Mouamin Maryam ${ }^{1}$, Mohamed Chakour ${ }^{2}$}

'Resident Doctor, Laboratory Department of Hematology, Avicenna Hospital, Faculty of Medicine and Pharmacy; Marrakech, Morocco; ${ }^{2}$ Professor of Higher Education, Laboratory department of Hematology, Avicenna Hospital, Faculty of Medicine and Pharmacy; Marrakech, Morocco.

\section{ABSTRACT}

Background: The myelogram is the collection of elements provided by microscopic examination of a hematopoietic bone marrow smears collected by puncture-suction. It is considered one of the most valuable diagnostic tools for assessing hematological abnormalities.

Methods: We conducted the present retrospective study of 305 patients collected over a 3 year period, from February 2015 through June 2018, performed in the hematology laboratory of the Avicenna military hospital in Marrakech to expose the main bone marrow indications, review its diagnostic contribution, evaluate the practice of the myelogram in our context, and propose recommendations to improve the practice of this examination.

Results: The myelogram study allowed to make the diagnosis of $53(17,4 \%)$ megaloblastosis cases, fifty five (18\%) cases of medullary plasmocytosis. Acute myeloblastic leukemia was found in 27 patients $(8.8 \%)$ followed by chronic lymphocytic leukemia in 11 patients (3.6\%), comes after chronic myeloid leukemia in 11 cases (4.3\%), while acute lymphoblastic leukemia is in 16 cases $(5.2 \%)$. The myelogram was normal in 60 cases (19.6\%). It objectified a reactional marrow in 49 cases (16\%). The myelogram was impossible to interpret in 21 cases $(7 \%)$, in which the sample was diluted.

Conclusion: This general review of haemopathies has highlighted the importance of the myelogram as an indispensable tool for diagnosis. In our study it was possible to know the contribution of this examination, which is linked to its good interpretation.

Key Words: Diagnosis, Hemopathies, Myelogram

\section{INTRODUCTION}

The myelogram is the collection of elements provided by microscopic examination of a hematopoietic bone marrow smears collected by puncture-suction. It includes the assessment of the smear richness in nucleated cells (megakaryocyte lineage included), the percentage of each cell category and their morphology [1]. It also detects the presence of parasites, infectious agents and tumour cells of spinal and extraspinal cord origin. Thus, it is a cytological examination which allows the qualitative and quantitative analysis of cells belonging to the hematopoietic medullary precursor compartment [2]. It is considered one of the most valuable diagnostic tools for assessing hematological abnormalities.

Its indications include diagnosis, classification and therapeutic follow-up of hematological diseases [3]. We conducted the present retrospective study to expose the main bone marrow indications, review its diagnostic contribution, evaluate the practice of the myelogram in our context, and propose recommendations to improve the practice of this examination.

\section{PATIENTS AND METHODS}

This is a retrospective study of a representative series of 305 patients collected over a 3 year period, from February 2015 through June 2018, performed in the hematology laboratory of the Avicenna military hospital in Marrakech.

The data collection was conducted using a farm return by excluding extensions assessment and non-hematological spinal disorders. In this study, all patients of both sexes regardless of age or socio-economic level were concerned.

\section{Corresponding Author:}

Boufrioua El Ghali, Resident Doctor, Laboratory department of Hematology, Avicenna Hospital Marrakech, Morocco. Email: boufriouaelghali@gmail.com

ISSN: 2231-2196 (Print)

ISSN: $0975-5241$ (Online)

Received: 02.02 .2019

Revised: 19.02.2019

Accepted: 03.03.2019 
All medullary punctures were performed in the departments with the doctors at the bedside of the patient. The location of the sampling was variable, the sternum facing the $2^{\text {nd }}$ intercostal space was the site of choice for adults, the anterior superior and posterior superior iliac spines were for the children.

The punctures were made with Mallarmé trocar and colored with May Grunwald Giemsa which is the reference color in hematology, it consists of applying two neutral dyes; the May-Grünwald's alcoholic solution, and Giemsa's 10\% diluted alcoholic solution. As for the coloration Perls it is performed on spinal cord smears as part of the primary classification of myelodysplastic syndromes, this coloring highlights insoluble cellular complexes containing iron: hemosiderin, Pappenheimer granules (fine iron-rich granules) = overloaded iron mitochondria. Determining Myeloperoxydase activity by testing (MPO) is routinely used for acute leukemia diagnosis. Its positivity represents a strong marker of myeloid differentiation.

Data entry and analysis were performed using the Microsoft Office Excel 2016 software for Windows version 10.0.

\section{RESULTS}

The mean age of patients was 42 years, with minimum age of 1 year and maximum age being 70 years. Children of less than 18 years represent $10 \%$ of our patients. A light male predominance was noted with a sex-ratio of 1,2 .

Fifty three percent of bone marrow smears performed on hospitalized patients in different services, mainly in the service of internal medicine with a rate of $43 \%$ and $47 \%$ was conducted on not hospitalised patients.

Hemogram disturbance was the first indication of myelogram, that is to say $53 \%$ of cases, followed by tumor syndrome in $23 \%$ of cases, then the suspicion of monoclonal gammapathy $17 \%$ of the cases (Table 1). Among the disturbances in blood count (CBC) listed, Macrocytic anemia was the most common abnormality with a rate exceeding $19 \%$, followed by normochromic normochromic anemia found in $14 \%$ of the cases. Bicytopenia and pancytopenia respectively represent $12 \%$ and $6 \%$ of all disturbances.

Among the 57 of macrocytic anemia cases found in the hemograms performed, 47 had megaloblastosis. Myelograms done within the framework of thrombocytopenia turned out to be normal, except for one patient who was in coma and suffers from thrombocytopenia and leukocytosis and in whom the myelogram showed acute myeloid leukemia. 18 myelograms were conducted on patients suffering from a pancytopenia: 15 had tumor associated syndrome, and their myelograms showed acute myeloid leukemia. Two cases of megaloblastosis, and one showed a dystrophic plasmocytosis.
Myelograms of 51 patients showed a bone syndrome with suspicion of gammopathy, had revealed; a multiple myeloma in 42 patients, chronic lymphocytic leukemia (CML) in three patients, 5 cases of reactive plasma cells, and 1 case of plasma leukemia.

In the case of splenomegaly; the myelogram objectified three medullary megaloblastosis and chronic lymphocytic leukemia.

Four myelograms were made for suspicion of medicinal side effects: two patients showed rheumatoid arthritis under methotrexate, following the discovery of a hemogram pancytopenia, and for which the myelogram revealed a case of megaloblastosis, and a normal marrow in the other case. Two patients with diabetes under sulfonamide who had thrombocytopenia, and for which the myelogram did not objectify abnormalities.

Ten myelograms were performed as part of a nephropathy assessment. Medullary plasmocytosis was found in seven cases, a CML in a case and a dystrophic pith in a patient with chronic kidney failure and a pancytopenia.

In total, the myelogram study allowed to make the diagnosis of $53(17,4 \%)$ megaloblastosis case, fifty five $(18 \%)$ cases of medullary plasmocytosis. Acute myeloblastic leukemia was found in 27 patients $(8.8 \%)$ followed by chronic lymphocytic leukemia in 11 patients $(3.6 \%)$, comes after chronic myeloid leukemia in 11 cases $(4.3 \%)$, while acute lymphoblastic leukemia is in 16 cases $(5.2 \%)$. The myelogram was normal in 60 cases $(19.6 \%)$. It objectified a reactional marrow in 49 cases $(16 \%)$. The myelogram was impossible to interpret in 21 cases $(7 \%)$, in which the sample was diluted (Table 2).

\section{DISCUSSION}

This work focuses on the contribution of the myelogram in the diagnosis of blood diseases, in the hematology laboratory at the Avicenna Marrakech military hospital has retrospectively noted an average prevalence of 101 myelogram / year. This average result is attributed to the participation of the hematology laboratory of the Mohammed VI University Hospital Centre of Marrakech, which supports a significant number of preformed myelograms. The sampling of this exam at University Hospital Centre of Treichville is 275 myelograms per year [1], and 1100 myelograms / year at the central hematology laboratory at Ibn Sina Hospital in Rabat in 2016 [2]. Compared to the hemogram, the myelogram is a relatively infrequent examination. This is due to the speed and ease of the conduct of the hemogram: thanks to automation. As for the myelogram, it also represents a major examination of major utility, but it has few indications compared to hemogram. 
The average age of patients in our series was 43 years, close to the average ages found in studies in Burkina Faso (42 years old) [4], of Cameroon (44,27) [5]. While the study conducted in Rabat [2] showed an average age of 14 years, this is explained by the predominance of the pediatric population in this series, which is $61 \%$.

The male predominance found in our study is comparable to the results reported in the studies of Casablanca $(1,4)$ [6], Bass-Normandy $(1,13)$ [7], in Senegal $(1,6)$ [8], Mali $(1,9)[9]$ in the Democratic Republic of Congo $(1,7)$ [10]. Men are more exposed to environmental factors than women because of their professional activity (use of herbicides and pesticides) $[11,12]$.

The most affected age group was 30 to 40 years old, whereas the study conducted in Rabat [2] found a high prevalence of malignant hemopathies (MH) in the age group 10 to 19 , this difference being explained by the fact that that our population was essentially an adult population $(90 \%$ of the patients were at least 18 years old).

We identified 11 main indications of the myelogram in our study; disturbances of the hemogram were the main indication, followed by tumor syndrome, these are the classic indications of the myelogram; Hugard [3], Ouattara [1] found similar results, concerning the frequency of a hemogram anomalies with predominance of pancytopenia in their series.

The blood count generally showed bicytopenia (anemia and thrombocytopenia) associated with variable leukocytosis. Anemia and thrombocytopenia were generally associated with leukocytosis in patients with $\mathrm{MH}$ in a series in Burkina Faso [13]. These biological signs have also been observed in Tunisia [12] and Cote d'Ivoire [14, 15]. Pancytopenia was also noted in $6 \%$ of patients. In fact, the circumstances of discovery of $\mathrm{MH}$, especially leukaemias, are generally signs of bone marrow failure more or less associated with a tumor syndrome [13].

Among the 57 macrocytic anemias, 47 had megaloblastosis with myelogram. This aspect is compatible with vitamin deficiency [16, 17], which have been confirmed by the corresponding vitamin dosages (folic acid and vitamin B12).

Lymphoproliferative syndromes are ranked first in the $\mathrm{MH}$ study in $24.5 \%$ of cases. A prevalence of lymphoproliferative syndromes of $67,3 \%$ was found in Ivory Coast [18]. Multiple myeloma represents $15.5 \%$ of the cases in our study, which was close to the $12.2 \%$ reported in Abidjan [19], but above the $7 \%$ average rates found in Mali and Senegal $[9,8]$. The CLL occupied $5.2 \%$ of the cases, unlike in Niger where it occupied $33.3 \%$. [20].

Acute leukaemias represent $13.1 \%$ (40 cases) of MH. They occupied the third position as nosological group in our study while in Ivory Coast study; they were in second with $21.3 \%$ of cases [21]. In the study by Seiter et al [22], acute myeloid leukemia (AML) represents $80 \%$ of acute leukemia (AL) in adults and $20 \%$ of acute children leukemia.

Myeloproliferative syndromes came fourth with 4.5\% (14 cases); in comparison with a Cameroonian study [21]. In our study, CML represents $4.2 \%$ of cases while other authors found higher proportions: 18.9 in Niger [20] and 9.3 in Ivory Coast [19].

In our series, we had only one patient in whom there was an appearance of hemophagocytosis in the myelogram. Confronted with other clinico-paraclinical data described in the literature [23], the diagnosis of macrophage activation syndrome (MAS) was retained.

We have 4 cases presenting different medicinal side effects: Two patients followed for rheumatoid arthritis under methotrexate that had pancytopenia. Pancytopenia under methotrexate at low doses is a rare but serious complication [24]. Its prevention is based on the close supervision of elderly patients, especially in cases of polypharmacy and hypoalbuminemia. The results of myelogram in these patients showed normal marrow in one and megaloblastosis in the other. This effect has been mentioned by several authors [24]. The other two patients with type 2 sulfamide diabetes had thrombopenia: known side effect of this treatment [25]. The myelogram in our 2 patients showed a normal aspect of the marrow which favors the immunological origin [25].

Reaction marrows were noted in $16 \%$ of patients in our series. This medullary reaction is not specific and is observed in a large number of pathological states (toxic, viral, parasitic) [25].

Diluted myelogram represented $7 \%$ of cases in our series. The most frequent causes of dilution were the technical errors during the sampling, the other causes of diluted marrow being: fibroses and medullary aplasias [26].

\section{CONCLUSION}

On a going back 3 years at Avicenna Military Hospital, this study allowed us to take stock of the hematological conditions diagnosed within our service. This general review of hemopathies has highlighted the importance of the myelogram as an indispensable tool for diagnosis. In our study it was possible to know the contribution of this examination, which is linked to its good interpretation, which is in turn directly related to the rigor of its performance. Highlight the various technical errors, and make recommendations to improve its implementation.

\section{Conflict of Interest}

The authors declare no potential conflicts of interest, financial or otherwise. 


\section{REFERENCES}

1. Ouattara S, Danho B, Kone M, Tea D. La pratique du myélogramme au CHU de Treichville : bilan de 19 années d'activité. Médecine d'Afrique Noire; 2000:47(5)

2. Omar El hamdaoui. L'apport du myélogramme dans le diagnostic des hémopathies: expérience du laboratoire central d'hématologie de l'hôpital Ibn Sina. Thèse de médecine. universite Mohammed V - rabat. Faculté de médecine et de pharmacie Rabat;2018,22 p.

3. HugardL, Bon J.C, Force -barge P, Porte J, RODIER J. Contribution à l'étude de la prévalence de l'anémie chez l'enfant en milieu tropical. CMS ELF-Congo - Pointe Noire. Méd. Afr. Noire 1997; 44 (1): 40-44.

4. Ouédraogo SM, Hien F, Bazié W, Millogo A, Drabo YJ. Place des hémopathies malignes en service de Médecine interne du CHU SouroSanou (Burkina Faso). Mali Médical 2011 ; XXVI : 17-21.

5. Moueleu N, Ngouadjeu D, Ngo S, Luma H. Épidémiologie des hémopathies malignes recensées en milieu hospitalier au Cameroun. Médecine et Santé Tropicales, Vol. 28, N8 1 - janvierfévrier-mars 2018

6. M. Harif, A. Benider, M. Bennani Othmani et al. Registre des cancers de la région du Grand Casablanca. Année 2005, 2006,2007, édition 2012.

7. www.orsbn.org/publication/bulletin_11.pdf. Mortalité par hémopathies malignes en Basse-Normandie. Le Bulletin de l'observatoire régional de la santé de Basse-Normandie numéro 11, Décembre 1997.

8. Thiam D, Diop TM, Tallarmin F, Toure AO, Diakhate L. Epidemiology and therapy of malignant hemopathies in Senegal. Hematol Cell Ther $1996 ; 38: 187-91$.

9. Diallo DA, Cissoko LS, Cissoko Y, et al. Epidémiologie actuelle des hémopathies malignes dans les services d'hématologie oncologie médicale et de médecine interne de l'hôpital du Point G, Bamako, Mali. Mali Medical 2005 ; 4 : 1-8.

10. Mufuta NJP, Mbayo K, Kayembe NZ, Gini EK, Mbuyi M. Cytologie des hémopathies malignes dans deux formations médicales de Kinshasa. Ann AfrMed $2013 ; 6$.

11. Henry K. Neoplastic disorders of lympho-reticular tissue in Henry K. and Symmers, W St C : Systemic Pathology : thymus, lymph node, node spleen and lymphatics. 3 rd Edition. London : Churchill Livingtone, 1992; p. 611960.

12. Elloumi M, Hafsia R, Omri EL, et al. Caractéristiques épidémiologiques, cliniques et cytohématologiques des leucémies aigués lymphoblastiques de l'adulte en Tunisie. Tunis Me 'dical $2002 ; 80: 199-202$

Table 1: Indications of the myelogram in our study

\begin{tabular}{|c|c|c|}
\hline Indication & $\begin{array}{c}\text { Number of } \\
\text { patients }\end{array}$ & Percentage (\%) \\
\hline Abnormalities of the CBC & 162 & 53 \\
\hline Tumor Syndrome & 72 & 23 \\
\hline Gammapathy & 51 & 17 \\
\hline nephropathy & 10 & 3 \\
\hline medicinal side effects & 4 & 1 \\
\hline Ungual plasmacytoma & 3 & 1 \\
\hline Neurobehcet & 1 & $<1$ \\
\hline Portall vein thrmbosis & 1 & $<1$ \\
\hline Others & 1 & $<1$ \\
\hline
\end{tabular}

13. Ouédraogo SM, Hien F, Bazie W, Millogo A, Drabo YJ. Place des hémopathies malignes en service de Médecine interne du CHU Souro Sanou (Burkina Faso). Mali Médical 2011 ; XXVI : 17-21.

14. Sangaré M, Kassi HY, N'Dogom M, Yayo-Ayé ME, Inwoley AK, Sawadogo D. Profil biologique des leucémies aigues non myéloides en Co ^te d'Ivoire. Rev Int ScMéd 2013 ; 15 : 49-53.

15. Sawadogo D, Lartey MT, Kouassi D, et al. Impact de la chimiothérapie sur les profils hématologiques et biochimiques au cours des hémopathies malignes à Abidjan. Cahier Santé2002 ; $12: 229-32$.

16. Sebahoun G, Sainty D, Horschowski N. Ponction médullaire et biopsie médullaire. Editions techniques. Encycl. Méd. Chir. (Paris, France), Hématologie 13000, A30,1991,7p.

17. Zittoun J, Zittoun R. Les anémies macrocytaires. Encycl. Méd. Chir. (Paris, France), Sang, 13002,A10,1985,14 p.

18. N'Dhatz Comoe E, Koffi KG, Ayemou R, et al. Prévalence et incidence des hémopathies malignes au CHU de Yopougon. Revintscme 'd 2012; 14 : 205-8.

19. Téa D, Yao T, Abissey A, Anoh J, Rain JD. Panorama des hémopathies diagnostiquées au laboratoire central du CHU de Treichville bilan de 10 années d'activité. Médecine d'Afrique Noire : 39-43.

20. Mounkaila B, Touré I, Gragnic G, MounkailaI. Hémopathies malignes à Niamey à propos de 90 observations sur 6ans. Méd Afr Noire 1996; 43: 472-5.

21. N'Dhatz Comoe E, Koffi KG, Ayemou R, et al. Prévalence et incidence des hémopathies malignes au CHU de Yopougon. Rev int sc méd $2012 ; 14: 205-8$.

22. Seiter K, Harris J. E. Myeloid leukemia staging. N Engl J Acute Med 1999; 341(11):807-813

23. Henter JI, Horne A, Aricó M, Egeler RM, Filipovich AH, Imashuku S, et al. Diagnostic and therapeutic guidelines for hemophagocytic lymphohistiocytosis. Pediatr Blood Cancer 2007; 48:124-131.

24. Sallah S, Hanrahan L R, Phillips D L. Intrathecal methotrexate induced megaloblastic anemia in patients with acute leukemia. Arch Pathol Lab Med. 1999 Sep; 123(9):774-7

25. Dearden C. Wade R. Else M. Richards S. Milligan D. Hamblin T. UK National Cancer Research Institute (NCRI), Haematological Oncology Clinical Studies Group, NCRI CLL Working Group. Blood 2008; 111:1820-1826.

26. Goldberg $\mathrm{C}$ et al. Bone marrow aspiration and biopsy transfusion. http://emedicine.medscape.com/article/207575, consulté le 24 oct. 2017.

Table 2: Pathologies diagnosed with myelogram in our study

\begin{tabular}{lcc} 
Pathologie & $\begin{array}{c}\text { Number of } \\
\text { patients }\end{array}$ & $\begin{array}{c}\text { Percentage } \\
(\%)\end{array}$ \\
Medullary plasmocytosis & 55 & 18 \\
Mégaloblastose médullaire & 53 & 17 \\
Acute myeloblastic leukemia & 27 & 9 \\
Chronic lymphocytic leukemia & 16 & 5 \\
Chronic myeloid leukemia & 11 & 4 \\
Acute lymphocytic leukemia & 13 & 4 \\
Macrophagic activation & 2 & 1 \\
Syndrome & & \\
Reactional marrow & 49 & 16 \\
\hline
\end{tabular}

